\title{
THE RELATION OF NITROGEN RETENTION TO NITROGEN INTAKE IN ADULTS WITH POST-TRAUMATIC MALNUTRITION
}

\author{
By BRUCE T. FORSYTH,1 MARGARET E. SHIPMAN, ${ }^{2}$ AND IRVIN C. PLOUGH ${ }^{3}$ \\ WITH THE TECHNICAL ASSISTANCE OF BETTY HACKLEY AND ALBERT FRYAR \\ (From the Department of Metabolism, Medical Division, Army Medical Service Graduate \\ School, Walter Reed Army Medical Center, Washington 12, D. C.)
}

(Submitted for publication May 10, 1954; accepted July 29, 1955)

Over a wide range of nitrogen intake, proteindepleted $(1,2)$ or growing rats $(3,4)$ retain increasing amounts of nitrogen as the dietary nitrogen is raised provided adequate calories are fed. Malnourished (5) or normal children (6) also increase nitrogen retention as nitrogen intake is raised, although some exceptions have been noted $(6,7)$. In malnourished adults it is apparent that some similar relationship between nitrogen intake and nitrogen retention is also present. For several reasons, however, the relationship between nitrogen intake and nitrogen retention in malnourished adults has not been well defined. In most adult studies, for example, caloric intake has frequently been substantially altered along with variations in nitrogen intake (8-13). In view of the known effect of non-protein calories on nitrogen metabolism (14) such studies become quite difficult to interpret. Equally difficult to interpret are studies $(7,11,15)$ in which fecal nitrogen analysis has been omitted. And finally it should be noted that in many instances study periods have been too short with no account taken of the variable time required for re-equilibration of nitrogen metabolism after a change in dietary nitrogen (9, $10,16-21)$.

In the present study, nitrogen retention was measured at various levels of nitrogen intake in a series of patients suffering from malnutrition after severe injury. In most of the patients at least two levels of nitrogen intake were employed, while caloric intake was kept constant. Balance periods were sufficiently long to allow for reequilibration of nitrogen metabolism after changes

\footnotetext{
1 Capt., MC, U. S. Army ; Present Address: 3720 Washington Boulevard, St. Louis 8, Missouri.

2 1st Lt., WMSC, U. S. Army ; Present Address : Army Medical Nutrition Laboratory, Denver, Colorado. ${ }^{3}$ Major, MC, U. S. Army.
}

in dietary nitrogen. In all studies fecal nitrogen analyses were performed.

\section{MATERIAL AND METHODS}

The thirteen subjects of this study were soldiers who had been severely injured or wounded in combat. Their individual case histories are recorded in the appendix. A patient's average body weight before injury was taken to be the pre-injury weight. In patients who had limbs amputated, the estimated weight of the amputated limb was subtracted from the pre-injury weight to give the corrected pre-injury weight. Lean body weight before injury was calculated using Behnke's (22) formula for Navy men; lean body weight in kilograms $=53.9$ (surface area in $\mathrm{M}^{2}$ ) -32.6 . Lean body weight at the start of study was determined by measurement of skinfold thickness using calipers with the specifications described by Brožek and Keys (23). The formula of Rathbun and Pace (24) was used to convert body specific gravity to per cent body fat. The estimated changes in body composition of each subject are presented in Table I.

All patients except patient number 7 received a liquid diet throughout these studies. Ten patients were studied at two or more levels of protein intake. As the protein intake was varied, the caloric intake and the ratio of carbohydrate to fat were maintained constant by calculation using standard food tables (25). In patients 3

TABLE I

Estimated changes in body composition at start of study

\begin{tabular}{cccc}
\hline & \multicolumn{3}{c}{ Percentage losses } \\
\cline { 2 - 4 } Patient & $\begin{array}{c}\text { Body } \\
\text { weight }\end{array}$ & $\begin{array}{c}\text { Lean body } \\
\text { weight }\end{array}$ & $\begin{array}{c}\text { Body } \\
\text { fat }\end{array}$ \\
\hline 1 & 14 & & \\
2 & 26 & 26 & 33 \\
3 & 16 & 13 & 70 \\
4 & 39 & 35 & 77 \\
5 & 26 & 24 & 72 \\
6 & 23 & 19 & 75 \\
7 & 32 & 29 & 68 \\
8 & 22 & 19 & 57 \\
9 & 23 & 21 & 49 \\
10 & 23 & 21 & 66 \\
11 & 19 & 35 & 72 \\
12 & 36 & 25 & 64 \\
13 & 26 & & \\
\hline
\end{tabular}


TABLE II

Composition of a representative liquid diet with three levels of protein intake

\begin{tabular}{|c|c|c|c|c|c|c|c|c|c|}
\hline \multirow[b]{2}{*}{ Food } & \multicolumn{3}{|c|}{100 Grams protein } & \multicolumn{3}{|c|}{180 Grams protein } & \multicolumn{3}{|c|}{270 Grams protein } \\
\hline & $\begin{array}{l}\text { Weight } \\
\text { grams }\end{array}$ & $\begin{array}{c}\text { Nitrogen } \\
\text { grams }\end{array}$ & $\begin{array}{l}\text { Energy } \\
\text { calories }\end{array}$ & $\begin{array}{l}\text { Weight } \\
\text { grams }\end{array}$ & $\begin{array}{c}\text { Nitrogen } \\
\text { grams }\end{array}$ & $\begin{array}{l}\text { Energy } \\
\text { calories }\end{array}$ & $\begin{array}{c}\text { Weight } \\
\text { grams }\end{array}$ & $\begin{array}{c}\text { Nitrogen } \\
\text { grams }\end{array}$ & $\begin{array}{l}\text { Energy } \\
\text { calories }\end{array}$ \\
\hline $\begin{array}{l}\text { Skim milk } \\
\text { powder } \\
\text { Cream } \\
\text { Eggs } \\
\text { Sugar } \\
\text { Total }\end{array}$ & $\begin{array}{l}140 \\
950 \\
200 \\
140\end{array}$ & $\begin{array}{r}8.0 \\
4.4 \\
4.1 \\
\\
16.5\end{array}$ & $\begin{array}{r}507 \\
1,938 \\
324 \\
539 \\
3,308\end{array}$ & $\begin{array}{l}400 \\
560 \\
200 \\
100\end{array}$ & $\begin{array}{r}22.8 \\
2.6 \\
4.1 \\
\\
29.5\end{array}$ & $\begin{array}{r}1,448 \\
1,142 \\
324 \\
385 \\
3,299\end{array}$ & $\begin{array}{r}700 \\
100 \\
170 \\
75\end{array}$ & $\begin{array}{r}39.9 \\
0.5 \\
3.5 \\
43.9\end{array}$ & $\begin{array}{r}2,534 \\
204 \\
275 \\
289 \\
3,302\end{array}$ \\
\hline
\end{tabular}

and 5 , nitrogen retention was also measured at a second caloric intake. The liquid diets were made up from skim milk powder, cream, eggs and sugar. The daily volume was approximately $1,400 \mathrm{cc}$. and was divided into six feedings: one glass every two hours from 8 A.M. to 6 P.M. Diets were prepared a day in advance; ingredients were weighed, and mixed with a measured volume of water in an electric blendor. Half diets were analyzed periodically in the laboratory. The composition of a typical liquid diet is given in Table II. Three to five days of ad lib. diet were allowed between diet study periods. All diets were supplemented daily with vitamin A 30,000 units, vitamin D 2,400 units, ascorbic acid 450 mgm., thiamine $12 \mathrm{mgm}$., riboflavin $18 \mathrm{mgm}$., nicotinamide $120 \mathrm{mgm}$., pyridoxine $7 \mathrm{mgm}$., folacin $3 \mathrm{mgm}$., and $B_{12}$ $3 \mathrm{mcg}$. Dietary potassium ranged from $0.51 \mathrm{mEq}$. per $\mathrm{gm}$. protein to $1.2 \mathrm{mEq}$. per gm. protein. The nitrogen balance technique used has been described (26). Body weights were determined daily, after voiding, before breakfast, on a scale accurate to $\pm 25 \mathrm{gm}$.

Statistical analyses of data were done using the methods of Fisher (27) and Ezekiel (28).

TABLE III

Nitrogen balance data

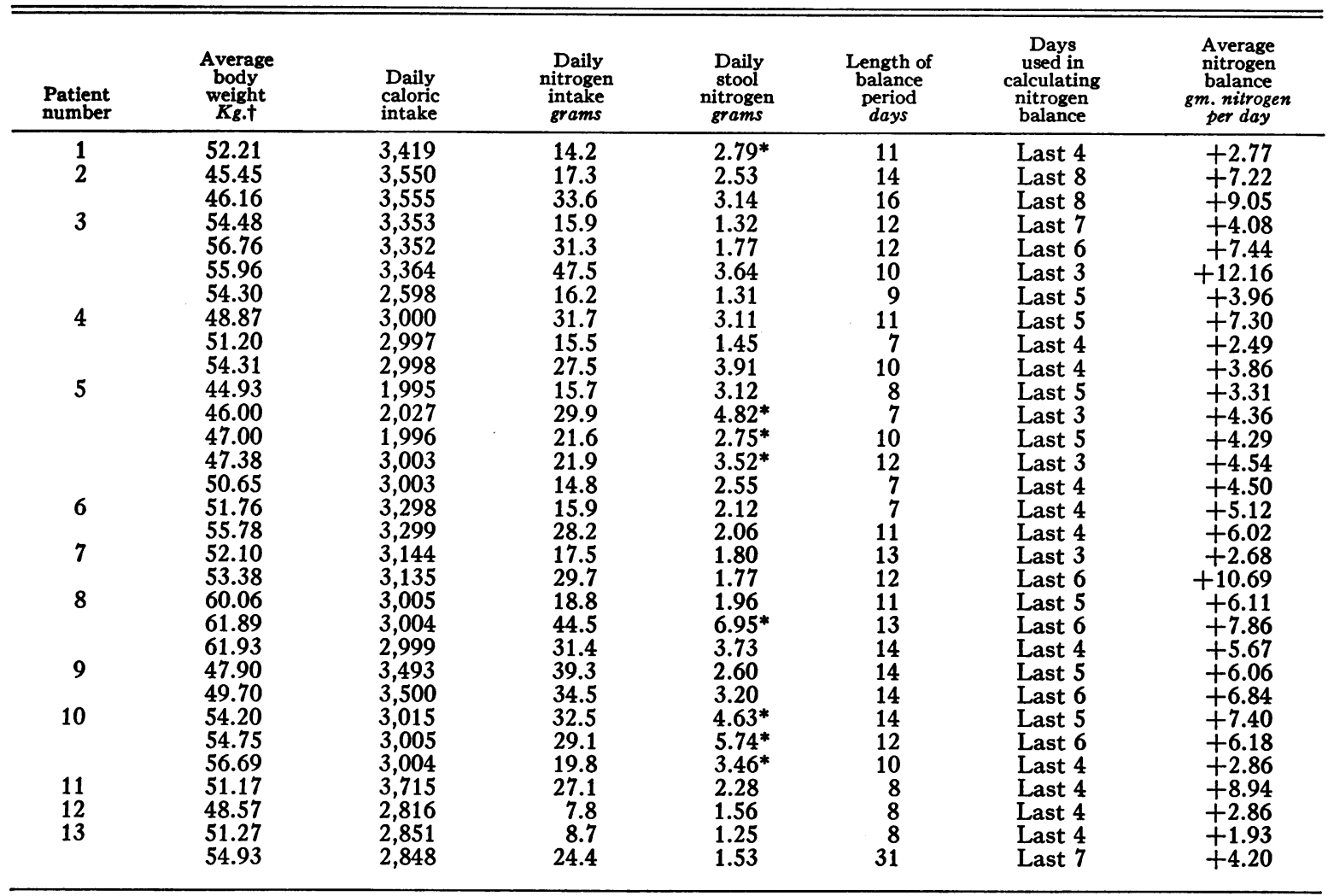

* Diarrhea during this stool collection period.

$\dagger$ The average of daily body weights on the days used for nitrogen balance calculation. 


\section{RESULTS}

When the dietary nitrogen is changed a variable time is required for adjustment of body processes to the new nitrogen intake. Characteristically, the first day or two after a higher nitrogen intake is begun the nitrogen balance is more positive than is the case after a few days on the diet. In order to select days which most accurately represent the nitrogen balance, the present data were analyzed, as represented in Figure 1, to determine the time needed to reach a steady urinary nitrogen excretion at three ranges of nitrogen intake. In each case the preceding ad lib. diets provided nitrogen intakes estimated to be from 0.2 to $0.25 \mathrm{gm}$. N per $\mathrm{Kg}$. per day. It can be seen that with diets containing $0.6 \mathrm{gm}$. or more $\mathrm{N}$ per $\mathrm{Kg}$. per day the urinary nitrogen excretion continued to rise through the fourth day of the new diet and then levelled off. With diets containing 0.4 to $0.59 \mathrm{gm}$. $\mathrm{N}$ per $\mathrm{Kg}$. per day, urinary nitrogen was relatively constant after the second day of the new diet. Urinary nitrogen excretion was nearly constant from the start with diets containing 0.16

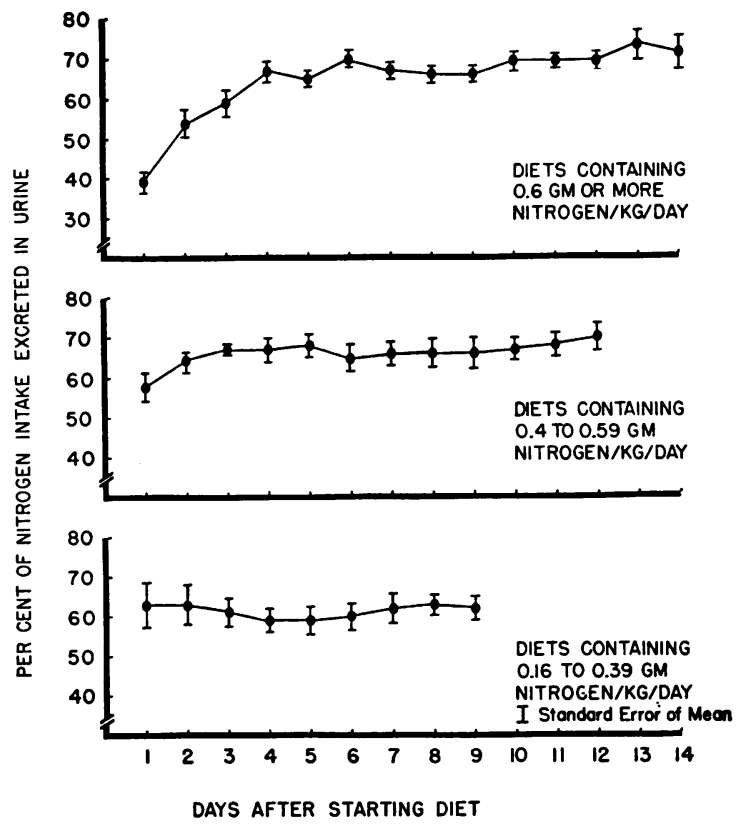

Fig. 1. Per Cent of Nitrogen Intake Excreted in the Urine with Three Ranges of Dietary Nitrogen, as a Function of Time After Starting Diet

to $0.39 \mathrm{gm} . \mathrm{N}$ per $\mathrm{Kg}$. per day, although the variability was greater during the first two days.

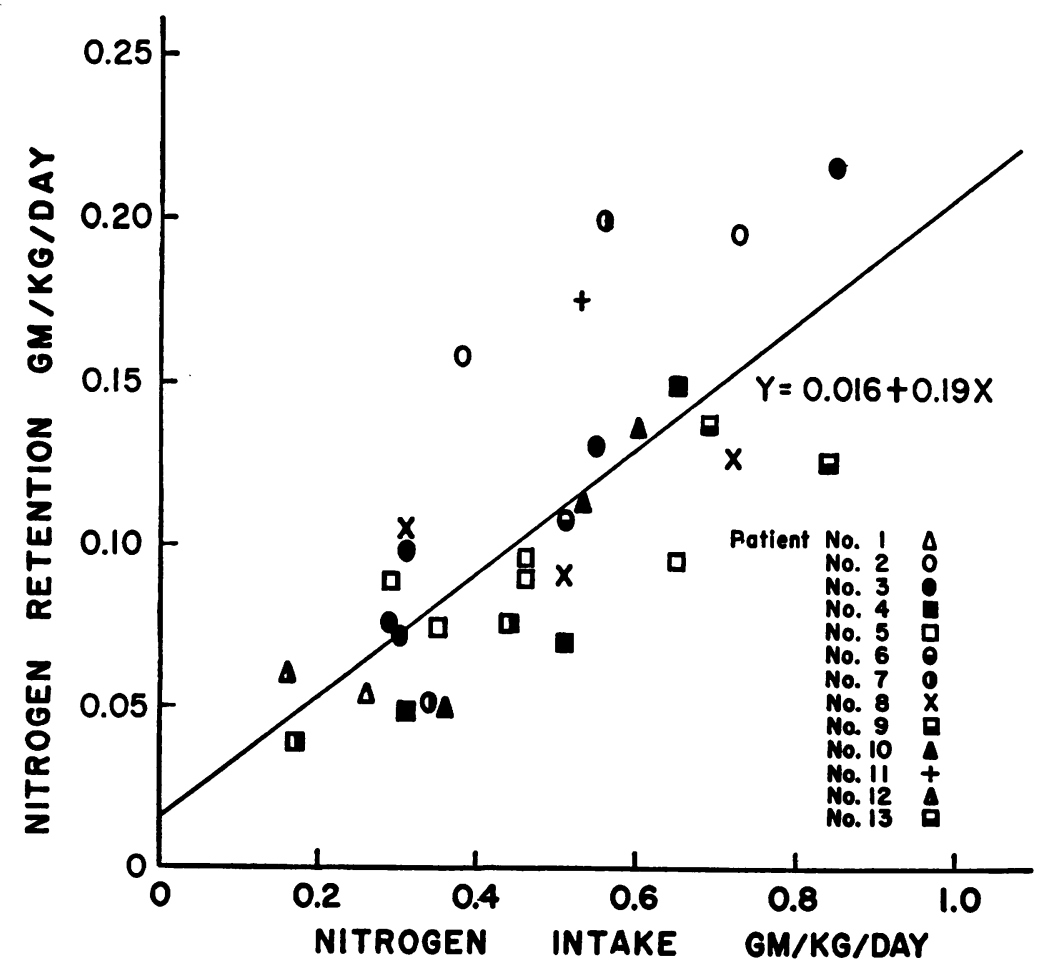

Fig. 2. The Relation of Nitrogen Retention to Nitrogen Intake 


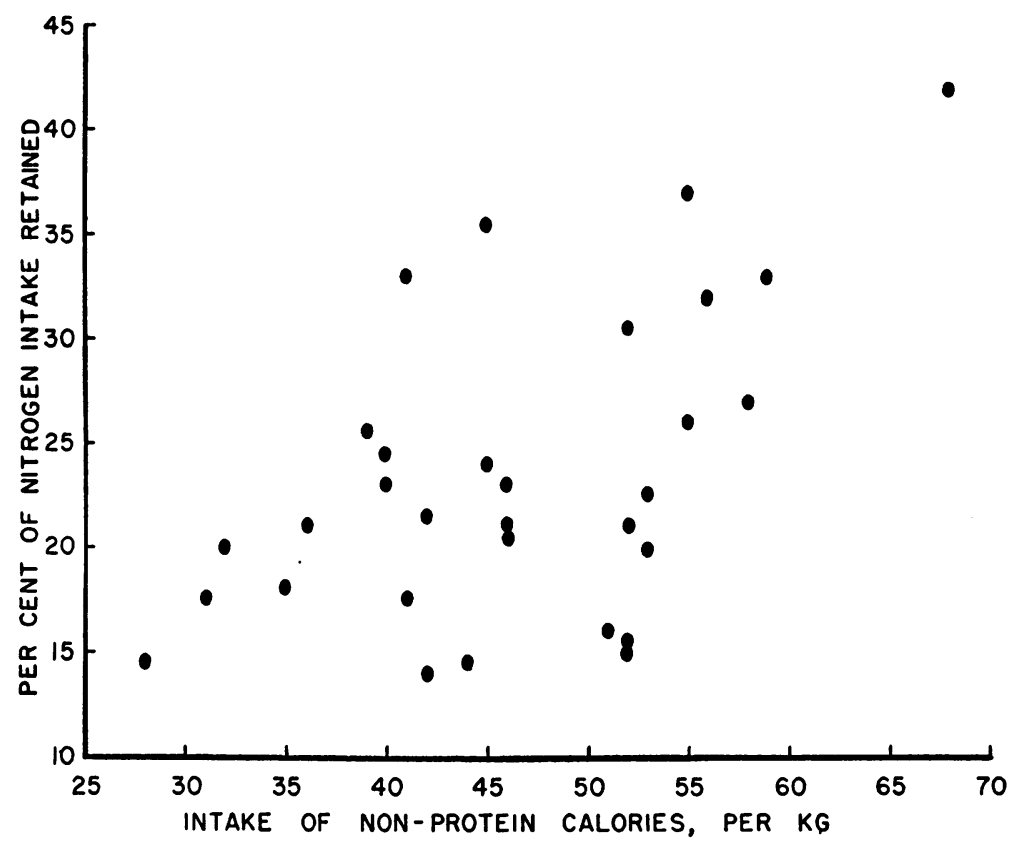

Fig. 3. The Relation of Non-Protein Calories to Per Cent of Nitrogen INTAKE RETAINED

In Table III are listed the results of the individual balance periods in the present study. In calculating nitrogen balances only the later days of each period were used in order to provide assurance that a steady state had been reached. In addition, the blood urea nitrogen was either stable or falling slightly during the days used for balance calculation.

From the data in Table III the coefficient of correlation between nitrogen intake and nitrogen retention (gm. per $\mathrm{Kg}$. per day) is 0.74 with $\mathrm{p}<$ 0.01. These data are shown in Figure 2, together with their regression equation. The equation is $\mathrm{Y}=0.016+0.19 \mathrm{X}$ where $\mathrm{Y}$ is nitrogen retention and $\mathrm{X}$ is nitrogen intake, both in gm. per $\mathrm{Kg}$. per day. The data show no tendency for the fraction of nitrogen intake retained to decrease at high levels of intake.

As noted in Table III, the liquid diet produced diarrhea in 8 of the 31 periods, with a resulting high fecal nitrogen. To exclude distortion of the results due to diarrhea, the relations between absorbed nitrogen (nitrogen intake minus fecal nitrogen) and nitrogen retention were calculated. A coefficient of correlation of $0.76(p<0.01)$ was found. The regression equation relating nitrogen retention $(Y)$ and nitrogen absorbed $(X)$, both in gm. per $\mathrm{Kg}$. per day, was $\mathrm{Y}=0.019+$ $0.21 \mathrm{X}$.

To assess the effect of non-protein calories on nitrogen retention a series of correlations were performed. Non-protein calories per Kg. vs. per cent of nitrogen intake retained gave a correlation coefficient of $0.53(\mathrm{p}<.01)$ (Figure 3 ); nonprotein calories per $\mathrm{Kg}$. vs. per cent of absorbed nitrogen retained, $0.52(p<.01)$. Each of these distributions has a single aberrant value; elimination of this reduces the coefficients to 0.41 ( $\mathrm{p}<$ $.05)$ and $0.36(p=.05)$, respectively. The ratio of non-protein to protein calories vs. per cent of nitrogen intake retained gives a coefficient of 0.39 $(p<.05)$; the ratio of non-protein to protein calories $v s$. per cent of absorbed nitrogen retained gives $0.48(p<.01)$. These two distributions have two pairs of aberrant values; their removal changes the coefficients to $0.35(p<.1)$ and 0.29 $(p<.2)$, respectively.

The possibility that avidity for retention of nitrogen is related to weight loss was also considered. No significant correlation was found between percentage loss of body weight, of lean body weight, or of body fat and per cent of dietary nitrogen retained. This possibility is also considered in Figure 4, in which are plotted individual 


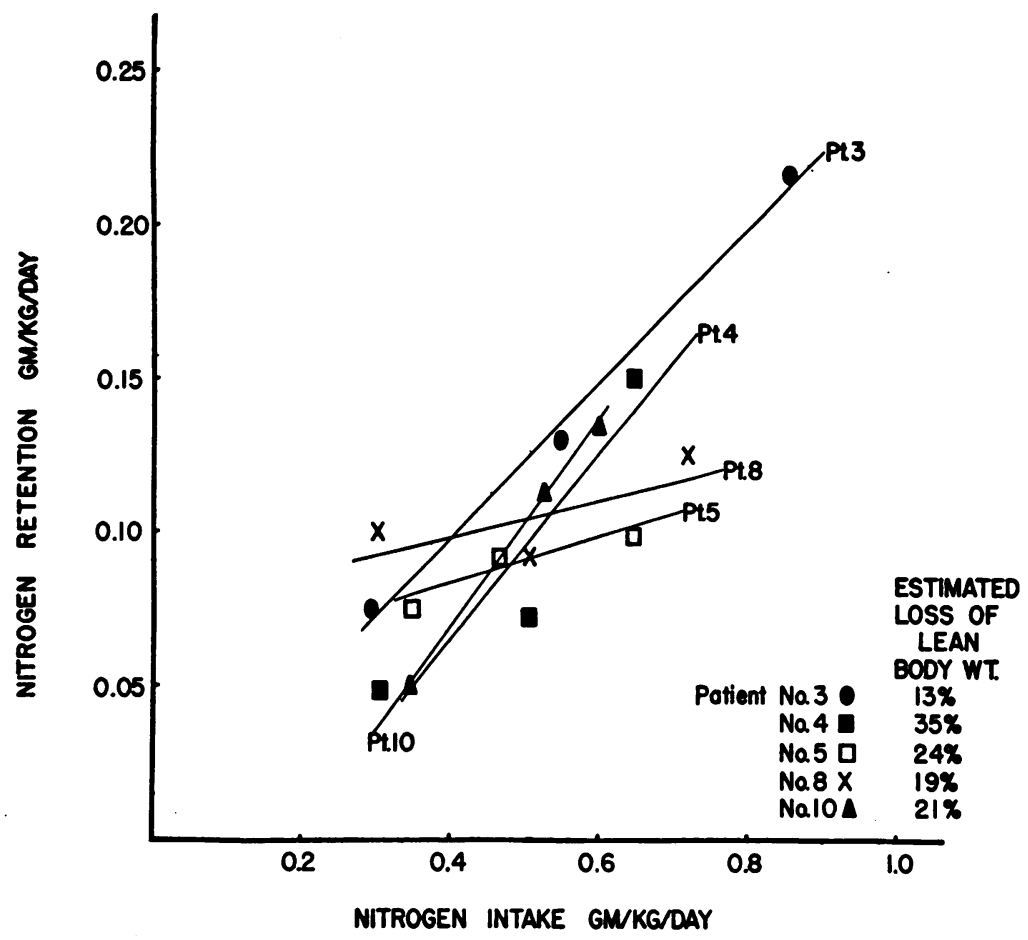

Fig. 4. Relation of Nitrogen Retention to Nitrogen Intake in Each Subject Who Received Three Levels of Dietary Nitrogen at Constant Caloric Intakes

No relation appears to exist between rate of nitrogen storage and estimated loss of lean body weight.

relations between nitrogen intake and nitrogen retention, drawn by best visual fit, for all patients with three isocaloric study periods. It appears in this small series that no relation exists between estimated loss of lean body weight and rate of nitrogen storage.

\section{DISCUSSION}

Patients with malnutrition are valuable subjects for the study of rates of nitrogen storage, since, for practical purposes, they can store unlimited amounts of nitrogen. The patients in the present series are a group with as near to uncomplicated malnutrition as may be found in a hospital population. All subjects were well into the anabolic phase of convalescence; all major wounds were healed and no significant infection was present.

Early studies of the response of malnourished men to various protein intakes $(8-10,20)$ led to the estimate that 60 to 70 per cent of the nitrogen intake was retained if the caloric intake was adequate. Five-day balance periods on any given diet were usual. These short periods did not allow for the lag in urinary excretion of nitrogen when a new diet was begun, and as a result a falsely high quantity of nitrogen appeared to be stored on high nitrogen intakes. In addition, as the protein intake was raised, the calorie intake was usually increased also; such caloric increments may also have tended to give falsely high values for nitrogen storage. The same criticisms may be directed at more recent studies (11-13, 16-21). The length of balance periods in the present study was sufficient to allow a stable urine nitrogen excretion and a stable blood urea nitrogen. The results so obtained permit the calculation of the relation, nitrogen retention $=$ $0.016+0.19$ times nitrogen intake, in gm. per $\mathrm{Kg}$. per day. The values of nitrogen retention calculated from this equation include 28 of the 31 observed values within limits of $\pm 0.05 \mathrm{gm}$. per $\mathrm{Kg}$. per day. Limits of $\pm 0.075 \mathrm{gm}$. per $\mathrm{Kg}$. per day 
include all but one value. The maximum deviation from predicted is $0.078 \mathrm{gm}$. per $\mathrm{Kg}$. per day. The dietary nitrogen intakes ranged from 0.16 to $0.85 \mathrm{gm}$. per $\mathrm{Kg}$. per day, equal to 1.0 to $5.3 \mathrm{grams}$ protein per $\mathrm{Kg}$. per day. The mean retention of dietary nitrogen was 23 per cent. This estimate of 23 per cent dietary nitrogen retained is similar to those obtained in other studies of malnourished adults. Strang, McClugage, and Brownlee (29) found a mean of 19 per cent (S. E. 4.0 per cent) dietary nitrogen retained, Beattie, Herbert, and Bell (12) a mean of 20 per cent (S. E. 2 per cent), Burger, Sandstead, and Drummond a mean of 24 per cent (S. E. 4 per cent) (13), and in the patients of Browne, Schenker, Venning, and Johnson (30) about one-third the dietary nitrogen was retained. Widdowson and Thrussell (31) found 40 per cent of the dietary nitrogen retained, but the caloric intake of their patients approximated 100 calories per $\mathrm{Kg}$. per day, a caloric intake so high that a higher degree of nitrogen retention might be expected. Malnourished adults with chronic nephritis (32) retained 22 per cent (S. E. 1.2 per cent) while malnourished children (5) retained 14 per cent (S. E. 1.8 per cent) of the dietary nitrogen. Thus a substantial body of evidence indicates a relatively constant relation of nitrogen retention to nitrogen intake over a wide range of nitrogen intake in malnourished humans who are ingesting adequate calories. Contrary to the findings of Von Hoesslin (9) there is no indication of less efficient use of protein as the protein intake increases.

Burger, Sandstead, and Drummond (13) and Beattie, Herbert, and Bell (12) have stated that the amount of nitrogen retention in malnourished men is related more specifically to calorie intake than nitrogen intake. The data used as the basis of the belief in the pre-eminent influence of calories on nitrogen metabolism are presented in Table 5 of Beattie, Herbert, and Bell's paper (12). However, using these data, correlation of the per cent of absorbed nitrogen retained with the ratio of non-protein calories gives a correlation coefficient of $-0.27(p>0.1)$. This negative correlation is due to the results in the patients of Group II where nitrogen and caloric intake were much lower than Group I and, as stated by the authors, may have been so low that any effect by non-protein calories could not be manifested. The correlation coefficient between these two measurements in the present series was $0.48(p<0.01)$; removal of two deviate values reduces it to the non-significant value of 0.29 .

Another approach to the question of the relative effects of caloric and nitrogen intakes is to analyze the relation of caloric intake, more specifically intake of non-protein calories per $\mathrm{Kg}$., and per cent of nitrogen intake retained. The data of Beattie, Herbert, and Bell (12) give a correlation coeffcient of $0.79(p<0.01)$, while those of the present series give $0.53(\mathrm{p}<0.01)$, or $0.41(\mathrm{p}<$ 0.05 ) removing the aberrant value. The reasons for these differences are unknown. However, it is apparent that the effect on nitrogen retention of non-protein calories is much less predictable than that of nitrogen itself.

The desirability of increasing nitrogen retention in malnourished patients has been commented on by many workers $(2,33,34)$. It would appear from the data of the present series and that reviewed that increased nitrogen retention may be much more readily accomplished by an increase in dietary nitrogen rather than an increased caloric intake, provided caloric intake is adequate initially. A calorie intake of 35 calories per $\mathrm{Kg}$. per day is considered adequate for patients comparable to those of the present series $(12,34)$.

The proposal that the degree of body weight loss determines the avidity for nitrogen in recovery from malnutrition was advanced by Rubner (35), and subsequently discussed by Wang, Hawks, and Hays (17). If the data of Wang, Hawks, and Hays (17) are analyzed statistically, no significant difference is present in the amount of nitrogen retained by the various groups studied with different degrees of underweight. Strang, McClugage, and Brownlee (29) found no relation between the rate of nitrogen storage and the degree of undernutrition of the patient, but Murray (36) found a more rapid weight gain in the more severely malnourished patients, although no nitrogen balance data are available in the latter instance. The data from the present series would indicate no apparent parallelism between estimated loss of lean body mass and rate of nitrogen storage.

\section{CONCLUSIONS}

1. Nitrogen retention is directly related to nitrogen intake in malnourished adults on adequate caloric intakes.

2. With nitrogen intakes ranging from $0.16 \mathrm{gm}$. to $0.85 \mathrm{gm}$. $\mathrm{N}$ per $\mathrm{Kg}$. per day no diminished ef- 
ficiency in the use of dietary nitrogen is evident at the higher levels of nitrogen intake.

3. Non-protein calories appear to have a relatively small effect on nitrogen retention.

4. In the present series the rate of nitrogen storage does not appear to be related to the degree of malnutrition.

\section{ACKNOWLEDGMENT}

The authors would like to thank M. C. Creditor, Captain, MC for use of his data on patients number 12 and 13, and L. L. Uzman, Captain, MC for his advice and help in preparation of this paper. The close supervision of patients given by J. Long, Captain, ANC, and her nursing staff is gratefully acknowledged.

\section{CASE SUMMARIES}

Patient No. 1, a 20-year old infantryman, height 67 inches, average pre-injury weight $65 \mathrm{Kg}$., was struck by mortar fire in August 1951, receiving compound comminuted fractures of the right humerus and left femur and multiple penetrating wounds of the right foot and left leg, requiring amputation of the left leg. A long series of orthopedic and plastic surgical procedures were required in rehabilitation, the last, an open reduction of the right humerus, was done in December 1952. During this period, the patient also suffered three relapses of malaria due to $P$. vivax. When the study was begun in February 1953, the patient weighed $52.2 \mathrm{Kg}$. and appeared moderately underweight.

Patient No. 2, a 25-year old infantryman, height 72 inches, pre-injury weight $72 \mathrm{Kg}$., stepped on a land mine in December 1952, suffering compound comminuted fractures of both tibias and fibulas and the left ilium; and multiple penetrating wounds of both thighs and buttocks and the right forearm. . The left leg was amputated during initial treatment; the right three months later, shortly before the start of the study. At that time, the patient weighed $44.5 \mathrm{Kg}$. and appeared markedly underweight. Anorexia, apathy, and marked lability of emotions were noted.

Patient No. 3, a 24-year old infantryman, height 67 inches, pre-injury weight $64 \mathrm{Kg}$., received a bullet wound in the left foot in November 1952, resulting in partial avulsion of the foot. After initial treatment, a series of reconstructive operations were done. At the beginning of the study in March 1953, the patient weighed 54.0 Kg. and appeared slightly underweight.

Patient No. 4, a 23-year old infantryman, height 71 inches, pre-injury weight $82 \mathrm{Kg}$., in October 1952 sustained multiple penetrating wounds resulting in compound comminuted fractures of the right tibia and fibula and left femur, right hemopneumothorax, and multiple superficial lacerations of the head and neck. Continuing treatment required amputation of the right leg and in- tramedullary nailing of the left femur. At the beginning of the study in May 1953, the patient weighed $46.0 \mathrm{Kg}$. Physical findings included moderate weight loss, healed right below-knee amputation stump, and a sinus tract at the site of the left femoral fracture draining purulent material from which was cultured hemolytic Staphylococcus aureus and E. Coli.

Patient No. 5, a 20-year old infantryman, height 68 inches, pre-injury weight $61.5 \mathrm{Kg}$., was wounded by small arms fire in April 1953 suffering avulsion of the anterior two thirds of the maxilla and hard palate, laceration of the tongue, and perforation of the sigmoid colon. Repair of the facial defect was begun at once; the perforated colon was exteriorized for ten days. Oral liquid diet was started a week after injury, but the patient continued to lose weight. When the study was begun eight weeks after injury, the patient weighed 45.3 $\mathrm{Kg}$. and appeared markedly underweight. The abdominal and facial wounds were well healed.

Patient No. 6, a 23-year old tank commander, height 67 inches, pre-injury weight $66 \mathrm{Kg}$., was injured by a gun explosion in March 1953, receiving second degree burns of the hands, face, chest, abdomen and thighs; a compound comminuted fracture of the right ilium, penetrating wound of the liver with right hemopneumothorax and avulsion of the skin and superficial muscles of the left upper abdomen and left lower chest. Six weeks later at the start of the study, the patient weighed $51.0 \mathrm{Kg}$. and appeared moderately underweight. All wounds had healed except an area of clean granulation tissue $20 \times 15$ $\mathrm{cm}$. over the right lower abdomen and upper thigh.

Patient No. 7, a 21-year old infantryman, height 70 inches, pre-injury weight $80 \mathrm{Kg}$., suffered bullet wounds in February 1953 resulting in multiple perforations of both large and small bowel, and severance of the left femoral artery. Amputation of the left leg above the knee was eventually necessary. At the beginning of the study in July 1953, the patient's wounds were healed, he weighed $49.5 \mathrm{Kg}$., and was moderately underweight.

Patient No. 8, 21-year old infantryman, height 69 inches, pre-injury weight $75 \mathrm{Kg}$., was injured by mortar fire in April 1953, receiving penetrating wounds of left side, including left arm, leg, abdomen, rupture of the spleen, laceration of the kidney, and fracture of the ilium. Recovery was complicated by thrombophlebitis. At the beginning of the study in June 1953, all wounds were healed and the thrombophlebitis had subsided. The patient weighed $58.8 \mathrm{Kg}$. and appeared moderately underweight.

Patient No. 9, a 17-year old infantryman, height 66.5 inches, pre-injury weight $62 \mathrm{Kg}$., suffered penetrating wounds of the skull, left eye, neck, left arm, right hip, and a compound comminuted fracture of the left tibia from a grenade explosion in May 1953. Treatment involved several craniotomies, a tracheotomy, and amputation of the left leg. When the study was begun in September 1953, the tracheotomy wound and amputation stump were not healing well. The patient weighed $44.9 \mathrm{Kg}$. and appeared moderately underweight. 
Patient No. 10, a 22-year old infantryman, height 67 inches, pre-injury weight $68 \mathrm{Kg}$., suffered multiple penetrating wounds of both thighs with severance of the right femoral artery in July 1953. Primary anastomosis of the artery was successful. In September 1953, at the start of the study, all wounds were healed and only moderate weight loss was evident. The patient weighed $52.0 \mathrm{Kg}$.

Patient No. 11, a 22-year old infantryman, height 72 inches, pre-injury weight $66 \mathrm{Kg}$., sustained perforating wounds of the left cheek, right chest wall, and both legs in June 1953. Amputation of the right leg was necessary. At the start of the study in October 1953 the patient appeared moderately underweight and weighed $50.0 \mathrm{Kg}$.

Patient No. 12, a 22-year old infantryman, height 72 inches, pre-injury weight $75 \mathrm{Kg}$., received multiple fractures of the pelvis, with rupture of the bladder in August 1953. By the time the study was started in September 1953, all wounds were healed but the patient was markedly underweight. He weighed $47.7 \mathrm{Kg}$.

Patient No. 13, a 21-year old infantryman, height 69 inches, pre-injury weight $68 \mathrm{Kg}$., was wounded in March 1953, receiving a compound fracture of the left femur with laceration of the femoral artery and sciatic nerve. Treatment required a number of operative procedures; the course was complicated by hepatitis in September 1953. When the study was begun in October 1953 the patient weighed $50 \mathrm{Kg}$. and appeared moderately underweight. Liver function tests were normal. There was some purulent drainage from the site of the femoral fracture.

\section{REFERENCES}

1. Benditt, E. P., Humphreys, E. M., Wissler, R. W., Steffee, C. H., Frazier, L. E. W., and Cannon, P. R., The dynamics of protein metabolism. I. The interrelationship between protein and caloric intakes and their influence upon the utilization of ingested protein for tissue synthesis by the adult protein-depleted rat. J. .Lab. \& Clin. Med., 1948, 33, 257.

2. Benditt, E. P., Woolridge, R. L., and Stepto, R., The dynamics of protein metabolism. II. The relationship between the level of protein intake and the rate of protein utilization by protein-depleted men and rats. J. Lab. \& Clin. Med., 1948, 33, 269.

3. Barnes, R. H., Bates, M. J., and Maack, J. E., The growth and maintenance utilization of dietary protein. J. Nutrition, 1946, 32, 535.

4. Forbes, E. B., Voris, L., Bratzler, J. W., and Wainio, W., The utilization of energy producing nutriment and protein as effected by the plane of protein intake. J. Nutrition, 1938, 15, 285.

5. Wang, C. C., Hawks, J. E., and Kaucher, M., Metabolism of undernourished children. VII. Effect of high and low protein diets on the nitrogen and caloric balance of undernourished children. Am. J. Dis. Child., 1928, 36, 1161.

6. Maroney, J. W., and Johnston, J. A., Caloric and protein requirements and basal metabolism of children from four to fourteen years old. Am. J. Dis. Child., 1937, 54, 29.

7. Farr, L. E., The assimilation of protein by young children with the nephrotic syndrome. Am. J. M. Sc., 1938, 195, 70.

8. Müller, A., Stoffwechsel-und Respirationsversuche zur Frage der Eiweissmast. Zentralbl. f. d. ges. Physiol. u. Path. d. Stoffwechs., 1911, N. F. 6, 617.

9. Hoesslin, $H$. von, Klinische Eigentümlichkeiten und Ernährung bei schwerer Inanition. Arch. f. Hyg., 1919, 88, 147.

10. Rubner, M., Utber den Stoffwechsel bei Unterernährung. Ztschr. f. d. ges. exper. Med., 1930, 72, 123.

11. Altshuler, S. S., Hensel, H. M., Hecht, P., and Pursley, R., Maintenance of nitrogen equilibrium by intravenous administration of amino acids. Clinical studies. Arch. Int. Med., 1942, 70, 749.

12. Beattie, J., Herbert, P. H., and Bell, D. J., Nitrogen balances during recovery from severe undernutrition. Brit. J. Nutrition, 1947, 1, 202.

13. Burger, G. C. E., Sandstead, H. R., and Drummond, J. S., Malnutrition and Starvation in Western Netherlands (Sept. 1944-July 1945). General State Printing Office, The Hague, 1948.

14. Munro, H. N., Carbohydrate and fat as factors in protein utilization and metabolism. Physiol. Rev., 1951, 31, 449.

15. Keys, A., Brozek, J., Henschel, A., Mickelsen, O., and Taylor, H. L., The Biology of Human Starvation. Minneapolis, University of Minnesota Press, 1950.

16. Hoobler, B. R., The protein need of infants. Being metabolism studies of a two months' old infant fed with varying proportions of cows' milk protein. Am. J. Dis. Child., 1915, 10, 153.

17. Wang, C. C., Hawks, J. E., and Hays, B. B., Metabolism of undernourished children. V. Protein metabolism. Am. J. Dis. Child., 1928, 35, 968.

18. Mulholland, J. H., Co Tui, Wright, A. M., and Vinci, V. J., Nitrogen metabolism, caloric intake and weight loss in postoperative convalescence. A study of eight patients undergoing partial gastrectomy for duodenal ulcers. Ann. Surg., 1943, 117, 512.

19. Co Tui, Wright, A. M., Mulholland, J. H., Caraloba, V., Barcham, I., and Vinci, V. J., Studies on surgical convalescence. I. Sources of nitrogen loss postgastrectomy and effect of high amino-acid and high caloric intake on convalescence. Ann. Surg., 1944, $120,99$.

20. Rubner, M., quoted by Lusk, G., The Elements of the Science of Nutrition, 4th Ed., Philadelphia, W. B. Saunders Co., 1928, p. 373.

21. Waife, S. O., Wohl, M. G., and Reinhold, J. G., Protein metabolism in chronic illness : Effect of protein supplementation on nitrogen balance, hemoglobin, serum proteins, and weight in the malnourished and the effect of the nutritional status on ni- 
trogen storage. J. Lab. \& Clin. Med., 1950, 36, 604.

22. Behnke, A. R., Lean body weight in relation to basal (standard) metabolism. Tr. New York Acad. Sc., 1953, 15, 74.

23. Brožek, J., and Keys, A., The evaluation of leannessfatness in man: Norms and interrelationships. Brit. J. Nutrition, 1951, 5, 194.

24. Rathbun, E. N., and Pace, N., Studies on body composition. I. The determination of total body fat by means of the body specific gravity. J. Biol. Chem., 1945, 158, 667.

25. Bowes, A. DeP., and Church, C. F., Food Values of Portions Commonly Used. 7th Ed., Philadelphia, College Offset Press, 1951.

26. Forsyth, B. T., Shipman, M. E., and Plough, I. C., The variability of fecal nitrogen excretion with liquid and solid diets. J. Lab. \& Clin. Med., 1954, $43,440$.

27. Fisher, R. A., Statistical Methods for Research Workers. 11th Ed., Edinburgh, Oliver and Boyd, 1950.

28. Ezekiel, M., Methods of Correlation Analysis. 2nd Ed., New York, John Wiley and Sons, Inc., 1941.

29. Strang, J. M., McClugage, H. B., and Brownlee, M. A., Metabolism in undernutrition. Its changes during treatment by high caloric diet. Arch. Int. Med., 1935, 55, 958.
30. Browne, J. S. L., Schenker, V., Venning, E. H., and Johnson, L. G., Further observations on the metabolically 'debilitated' patient. Effects of various levels of dietary protein and calories on nitrogen metabolism, body weight and urinary corticoids. Conference on Metabolic Aspects of Convalescence, Josiah Macy Jr. Foundation, 14th Meeting, November 12-13, 1946, p. 170.

31. Widdowson, E. M., and Thrussell, L. A., XXVI. The absorption and excretion of nitrogen, calcium, magnesium and phosphorus in Studies of Undernutrition, Wuppertal, 1946-49, London, H. M., Stationery Office, 1951, Special Report Medical Research Council, No. 275, pp. 296-311.

32. Keutmann, E. H., and Bassett, S. H., Dietary protein in hemorrhagic Bright's disease. II. The effect of diet on serum proteins, proteinuria and tissue proteins. J. Clin. Invest., 1935, 14, 871.

33. Cannon, P. R., Amino acid utilization in the surgical patient. J. A. M. A., 1947, 135, 1043.

34. Pollack, H., and Halpern, S. L., Therapeutic Nutrition. Washington, D. C., National Research Council, Publication No. 234, 1952.

35. Rubner, M., quoted by Cathcart, E. P., The Physiology of Protein Metabolism. 2nd Ed., p. 110. London, Longmans, Green and Co., 1921.

36. Murray, R. O., Recovery from starvation. Lancet, 1947, 1, 507. 